\title{
A SEED Fejlődési Skála mint a 0-4 éves korú gyermekek egyik vizsgáló eljárása az eltérő fejlődésmenet diagnosztikájában
}

\author{
Tóth Anikó \\ Budapesti Korai Fejlesztő Központ
}

\begin{abstract}
A SEED Fejlődési Skála (Sewall Early Educational Development Scale) 0-4 éves korig méri a csecsemők és a gyermekek adaptációs, pszichomotoros képességeit. A Skála alkotói több intelligencia teszt résztesztjeit, feladatait alkalmazták egy fejlödési skálában annak érdekében, hogy a gyermekek képességeit körvonalazni tudják a korosztályuknak megfelelöen, erősségeiket és gyengébb képességeiket is feltérképezzék, ezzel meghatározva a fejlettségi szintet, valamint a képességeik struktúráját. Mindezt elsősorban azért tették, hogy a megvizsgált, és eltérő fejlettségi szinten teljesítő gyermekek fejlesztésének irányvonalát, hangsúlyait a lehetö legpontosabban körvonalazni tudják, valamint, hogy a gyermekek későbbi fejlődésmenetének nyomon követése is biztositott legyen ezzel a vizsgáló metódussal.

A skála eszközkészlete és feladatrendszere lehetővé teszi a gyermekek spontán tevékenységének megfigyelését, így a vizsgálati helyzetben olyan gyermekek esetén is eredményt kapunk fejlettségi szintjükröl, akiknél bármilyen okból kifolyólag (figyelemzavar, magatartási problémák, értelmi elmaradásból adódó alacsonyabb szintü feladattartás stb.) az együttmüködés nehezített:

A Skála elsősorban a fejlettségi szint megállapítása mellett segíti a fejlesztési lehetőségek, azok irányvonalának megfogalmazását, így a beavatkozás szakszerüen, időben, a gyermek együttmüködési készségétöl függetlenül elkezdődhet.

Értékelési rendszere fejlettségi kort határoz meg, ill. az elmaradás mértékét.
\end{abstract}

Kulcsszavak: kora gyermekkori intervenció, fejlődési vizsgálatok, fejlődési skála, SEED Fejlödési Skála, eltérő fejlődésmenet

\section{Bevezetés}

Ma hazánkban is egyre természetesebb, hogy a gyermekek képességeit egyre korábban, ha lehetséges a megszületést követően közvetlenül monitorozzák a szakemberek. Az újszülöttek esetében ez inkább egészségügyi szűrő eljárásokat jelent, de azon gyermekek esetén, akiknek a fejlődésmenete veszélyeztetett (pl. koraszülöttek, intrauterin ártalmakat szenvedő csecsemők stb.) egyre elterjedtebb, hogy a fizikális vizsgálatokkal párhuzamosan a fejlődésbeli rizikót más vizsgáló módszerekkel is megállapítsák a legkorábbi életszakaszban. Mindez lényeges azért, hogy a speciális segítséget igénylő gyermekek és családjaik minél korábban kerüljenek szakellátásba, a problémájuknak leginkább megfelelő terápiás és fejlesztő eljárások, tanácsadás, szociális segítségnyújtás legyen számukra a lehető legkorábban, személyre szabottan elérhető.

„A koragyermekkori intervenció mindazon szolgáltatások/ellátások összessége, amelyek az iskoláskor előtti életszakaszban speciális segítséget igénylő gyermekekre és családjaikra irányulnak. A koragyermekkori intervenció a szürés szakaszától, a probléma felismerésétől és jelzésétől kezdve a minősítésen és diagnosztizáláson át magában foglalja a különböző terápiás, illetve a gyógypedagógiai fejlesztő és tanácsadó tevékenységet is. Szemléletében kiemelten fontos a prevenciós elem. A speciális segítségnyújtás egyrészt a gyermek személyes fejlődése, a család saját kompetenciájának megerősítése, a család és a gyermek szociális befogadása érdekében történik." (EADSNE, 2005-2010; Kereki, 2014) A csecsemők, kisgyermekek fejlődési esélyei annál inkább adottak, minél korábban meg- 
kezdődik a terápiás, fejlesztő és a család számára lényeges tanácsadói támogatás, kísérés. Ennek tehát alapfeltétele, hogy minél korábban detektálódjék a speciális szükséglet.

Mindehhez olyan vizsgáló eljárásokra van szükség, melyek speciálisan a legfiatalabb életkorban (0-3 év) mérik a gyermekek képességeit, de ezek mellett jól támogatják a fejlesztő/terápiás segítségnyújtás megtervezését is.

Az OECD országokban a sajátos nevelési igényű (SNI) csoport ellátásában kétféle modell működik, írja Kereki J. és Lannert J. a TÁRKI-TUDOK 2009-es tanulmányában (Kereki, 2014). Az egyik a „részletes szükségletprofilra épülö, fejlesztési területeket megjelölö, eredményértékelő, -követő rendszer", amely magasan képzett szakemberigénye, magas eszköz és infrastruktúra-szükséglete miatt inkább a fejlettebb országokban müködik. A másik, amely hazánkban is használatos, a diagnosztikus kategóriákat alapul vevő rendszer. Ennek alapfeltétele, hogy standardizált, komplex diagnosztikai eszközrendszer álljon rendelkezésre azon intézményekben, ahol komplex fejlődési diagnosztikai munkát végeznek. Ehhez azonban Magyarországon, mint azt a szerzők leírják heterogén a vizsgáló eszköztár, vagy már nem korszerü, vagy nem standardizált, illetve nem teljesen jogszerűen alkalmazott vizsgáló eszközök használatosak. A tanulmányban olvashatjuk, hogy a 0-3 éves korban leggyakrabban alkalmazott vizsgáló eljárás a megfigyelés, emellett a szakemberek által is elavultnak jellemzett Brunet-Lezine teszt, vagy a magyar standarddal még nem rendelkező Bayley II., ill. Bayley III. Fejlődési Skála. Mindez azt jelzi, hogy a korai életszakaszban a diagnosztikai munkában eléggé eszköztelenek a szakemberek, személyes tapasztalatra, egyéni, magas szakmai színvonalú tudásra van ahhoz szükség, hogy megfelelő fejlődési diagnózist tudjanak felállítani.

Az itt bemutatott SEED Fejlődési Skála természetesen nem egyedüli megoldásként jelentkezik, de megismertetésével szándékunkban áll egy olyan vizsgáló eljárást bemutatni, mely alternatívát ad a komplex diagnosztikai folyamat eszköztárában. Metódusában megjelenik az a korszerü szemlélet is, mely szerint a deficitorientált diagnosztikai kategóriaképzést felváltja egy szükséglet-térkép, mely nem csak a vizsgált gyermek képességstruktúráját rajzolja ki, hanem a család mindennapi helyzeteihez, életminőségének alakításához is támpontokat nyújt. Emellett használata egyszerü, eszközkészlete, valamint a vizsgálat menete a gyermeki sajátosságokat követi, lehetővé téve, hogy a bármilyen okból kevésbé együttműködő, viselkedésproblémával élő gyermekről is képet kapjunk a fejlesztés megkezdésének kiindulópontjául.

\section{Diagnosztikai folyamat}

A SEED Fejlődési Skála nem önmagában jelenti a gyakorlatban való jó használhatóságát, hanem egy olyan kontextusban, mely épít a diagnosztikai folyamatban a különböző szakterületek együttes munkájára, a különböző szakterületen dolgozó szakemberek team-munkájára, valódi együttes jelenlétére a vizsgálat ideje és a kapott eredmények, javaslatok családdal történő megbeszélése alatt. Ez a módszertani alapelv jellemzi a Budapesti Korai Fejlesztő Központ diagnosztikai munkáját is. A Központ megalakulása óta szószólója és szakmai úttörője a hazánkban terjedő korai fejlesztésnek, kora gyermekkori intervenciós szemlélet magyarországi elterjesztésének, a komplex diagnosztikai módszertannak. A koragyermekkori intervención belül végzett fejlődési diagnosztikai munka a Központban szakorvos, gyógypedagógus/pszichológus és mozgásfejlesztő szakember együttműködésével valósul meg.

„A vizsgálat célja a gyermek tudásának és erőforrásainak feltérképezése, valamint a fejlődési lehetőségek minél teljesebb felhasználásához hozzásegítő tanító/ gondozó környezet megismerése. Ezt a munkát módszeres megfigyelések, és az öszszegyűlt információk értelmezéseinek egysége jellemzi. A vizsgálati folyamat a szülő 
(gondozó) és a szakemberek együttmüködésén alapul. A vizsgálati folyamat meghatározott sorrendet követ, mely elsőként a személyes kapcsolatok kialakítását, ezt követően az információk, adatok gyűjtését, majd végül a további tevékenységek megtervezését jelenti. A vizsgálat alapját a gyermek és a szülő (a gyermek legbizalmasabb gondozója) közötti kapcsolat és interakció teremti meg." (Matesz és Tar, 2010)

\section{Fejlődési Skálák jellemzői}

A fejlődési skálákat születéstől 4-6 éves korig használjuk, tehát a koragyermekkori intervenció eszköze. „Ez a vizsgálati technika különösen kisgyermekek, csecsemők pszichológiai megismerésénél előnyös." (Lányiné, 2004. 94. o.)

„A skála nem kifejezetten teljesítmény teszt, mert nem csak a vizsgálati helyzetben mutatott funkciókat méri fel, hanem támaszkodik az informátor tudására, emlékezetére a gyermek viselkedéses teljesítményeire vonatkozóan. Tesztnek tekinthető azonban anynyiban, hogy pontosan meghatározottak a körülmények, ahogyan végezni és értékelni kell a vizsgálatot, a normák, amelyekhez viszonyítunk, előzetes standardizálás eredményei és a számszerü értékelés is a tesztekkel rokon." (Lányiné, 2004. 95. o.)

„... a fejlödési skálák az emelkedő életkorral fokozatosan nehezedő sorrendben felsorolják azokat az általában pszichomotoros, szenzoros és szociális funkciókat, amelyek leginkább jellemzik egy-egy kor fejlettségi színvonalát, képességleltárát." (Lányiné, 2004. 94. o.)

A gyermekek fejlődésmenete egyéni módon, eltérően alakul, saját tempójukat követve. Egyes gyermekek kiemelkedő képességűek, korukhoz képest hamarabb lépnek előre, mások a kortársaktól lemaradva lassabban teljesítik az elvártakat. A fejlődés menetére jellemző az is, hogy akadnak olyan gyermekek, akik egyes területeken mutatnak elmaradást, míg mások több fejlődési területen is. Előfordulhat az is, hogy egy kisgyermek szórt teljesítmény képet mutat. Az eltérő, megkésett fejlődésmenet felismerése fontos szerepet játszik abban, hogy a korai életszakaszban megkezdődhessen a fejlesztés, így a kialakult elmaradást esetleg behozhassa a gyermek, vagy ha képességeinek határai ezt nem teszik lehetővé, akkor megakadályozzuk, vagy enyhítsük a másodlagosan kialakuló, általában a viselkedésben megjelenő problémákat. A fejlődési skálák mindemellett segítenek nyomon követni a rizikó csoportba (pl.: koraszülött, dysmaturus, intrauterin ártalmakat szenvedő) tartozó újszülöttek fejlődésének menetét.

A fejlődési skálák könnyen áttekinthetőek, könnyen alkalmazhatóak, és könnyen adminisztrálhatóak. Ezen előnnyel együtt is pontos képet adnak a gyermek fejlettségi szintjéről, az elmaradás mértékéről és területéről. Ezeket együttesen fejlettségi kornak (FK) nevezzük. A fejlettségi kort megadja a skálával felvett - elemzett és értékelt -, elért eredmény.

\section{A SEED Fejlődési Skála története}

Történetét tekintve a SEED Fejlödési Skála megalkotása, gyökere az Amerikai Egyesült Államokba, Denverbe, alkalmazásának kezdete az 1970-es évekre nyúlik vissza.

Dr. Henry Sewall denveri gyermekorvos 1944-ben (már 71 éve) alapított egy intézményt, ahol teljes körü ellátást biztosított fogyatékkal élő személyek részére. Az 1970-es években megbízási projekt keretében kezdtek a korai életszakaszban történő ellátás jellegzetességeinek feltárásába. Az intézményben -szemléletében korát megelőzve- több szakma képviselője dolgozott együtt az eltérő fejlődésmenetű gyermekek fejlesztésében, így kézenfekvő volt, hogy együttesen gondolkodnak a probléma feltárásán, és olyan rend- 
szert építettek ki, mely több szakterület szakembereinek együttes jelenlétében egy helyen biztosítja a diagnosztikai vizsgálat majd a különböző terápiás és fejlesztési eljárások elérhetőségét. Tapasztalataik alapján kidolgozták a SEED Fejlődési Skálát, az akkor Amerikában használt, standardizált vizsgáló módszerek releváns itemeinek, és eszköz készletének felhasználásával. Olyan pszichomotoros funkciókat emeltek ki a tesztek, skálák összevetése következtében, melyek jól mérik a gyermekek adott korban elvárható teljesítményeit. A skála megalkotásakor célul tüzték ki, hogy gyors obszervációs eszközt alkossanak, mely a gyermek által ismert környezetben is felvehető. Eszköztára úgy került összeállításra, hogy a gyermekek közelében előforduló játéktárgyak, könyvek, eszközök akár kiválthassák azokat, amennyiben a gyermek számára idegen, nem ismert eszköz akadályozza a teljesítményét, képességeinek megmutatását. A feladatok szövegezésénél külön figyelmet fordítottak arra az alkotók, hogy kerüljék a szakkifejezéseket, mely lehetővé teszi, hogy a gyermeket akár az őt jól ismerő gondozója támogassa a vizsgálati helyzetben. A SEED Fejlődési Skála a korábbi vizsgáló eljárásokhoz képest részletesebb abban, hogy több területet is bevont a vizsgálódásba. Az adaptáció, gondolkodói készségek a nagymozgás, beszéd és szociabilitás mellett az öltözködés, táplálkozás, önellátás külön területet képez.

A Sewall által képviselt transzdiszciplináris megközelítés forradalmi volt a hetvenes években. A gyermeket holisztikus szemlélettel közelítették meg, nem csak a betegséget gyógyították, hanem figyelembe vették testi szellemi és érzelmi egységét is. Természetes volt számukra az a felismerés, hogy a gyermekek teljesítményét környezetük formálása, a megfelelő légkör és helyszín is befolyásolja. Már működésük kezdetétől fogva a szülőket is bevonták a gyermek megismerésébe, fejlesztésébe. A Skála megalkotásával az intézményben dolgozó szakembereknek az volt a célja, hogy olyan, a munkájukat segítő vizsgáló eszközt állítsanak össze, amely nem deficit orientált, hanem azt mutatja meg, hogy mit tud a gyermek, rámutat az elért eredményekre, mely segíti a fejlesztés irányának meghatározását.

Magyarországon a Budapesti Korai Fejlesztő Központban használták először a SEED Fejlődési Skálát. Dr. Gallai Mária, Dubecz Dorottya és Czeizel Barbara 1993-as amerikai tanulmányútjukon ismerkedtek meg ezzel a más szemléletet sugalló intézménynyel és fejlődési skálával. Törekvésük, hogy Magyarországon létrehozzanak egy olyan intézményt, mely egy helyen biztosítja a hozzájuk forduló családok számára a fejlődési vizsgálatot, a fejlesztést és a szülőknek szóló tanácsadást, egybecsengett az amerikában már müködő mintával. A fejlődési skálát használatukra bocsátották, ekkor fordította le magyarra Dr. Gallai Mária, gyermekorvos. A Budapesti Korai Fejlesztő Központban 1993 óta használják a SEED Fejlődési Skálát diagnosztikai támpontnak, vizsgáló eljárásként.

A Skála használatának hosszú éves gyakorlati tapasztalatai beépültek az értékelési rendszerébe, és tovább fejlődtek a Központ diagnosztikai munkájának megfelelően a vizsgálati eredmények megfogalmazásában. A kvantitatív mutatók mellett a Központ munkatársai nagy hangsúlyt fektetnek a gyermeki viselkedés és teljesítmény minőségi megragadására is, melyhez a SEED Fejlődési Skála értékelési rendszere megfelelő keretet és egyben szabadságot biztosít.

\section{A SEED Fejlődési Skála alkalmazása a vizsgálati folyamatban}

A vizsgálati folyamat a problémafelvetéssel kezdődik. Valamely szűrővizsgálat eredménye, vagy a tágabb, vagy szükebb család, a szülők gyanúja veti fel a fejlődési vizsgálat szükségességét, indítja el egy komplex vizsgálat megszervezését.

A diagnosztikai munka az anamnézis felvételével kezdődik. A kérdések kiterjednek a születés elötti, a születés körüli és közvetlenül azt követő időszakra. Emellett 
fontos, hogy a szülő beszámoljon a gyermek eddigi fejlődésének menetéről, szokásainak alakulásáról, valamint viselkedésének föbb jellemzőiről. Ezt követi a gyermek jelen állapotának megfigyelése.

Megfigyelést alkalmazunk kidolgozott keretbe ágyazott vizsgálati eszközök használatával is, valamint a Skála felvétele során tett megfigyeléseink is alapját képezik a kvantitatív elemek mellett a minőségi jellemzők megragadásának. Megfigyeljük a gyermek kontaktuskészségét, kooperabilitását, általános viselkedését, spontán tevékenységének minőségét, játékának szintjét, érzékszervi állapotát, figyelmének tartósságát és terjedelmét, kommunikációját, beszédállapotát, mozgásának állapotát (finom-, és nagymotoros mozgások, mozgásszabályozás, izomtónus, mozgásritmus) , valamint a vizsgáló irányításának fogadását. A gyermekek vizsgálatakor a megfigyeléseket összegezzük a figyelem/éberség mentén, vagyis obszerváljuk az érzelmi megnyilvánulásokat, a csecsemő energikusságát, érdeklődését a teszt ingerei/eszközei iránt, felderítését, orientálódását a vizsgáló felé. Figyelmünk fókuszába a teljesítmény mellett a játéktevékenységek közben a gyermek és szülő interakciója során megfigyelhető kvalitatív jellemzők is állnak. Mindezek rámutatnak arra, hogyan használja a csecsemő, kisgyermek a tudását, mik a motivációi, megelégedést kiváltó tevékenységei (emocionális tapasztalati minták), és feltérképezhetőek a kommunikációs stratégiái.

A megfigyeléseket a vizsgálat során a gyermekek szabad tevékenységei közben, illetve a skála feladatainak végzése közben is tehetjük. A gyermek spontán aktivitását figyelve kezdhetünk hozzá a fejlődési skála eszközeinek átváltásához és végezhetjük el a pszichomotoros fejlettség vizsgálatát (Matesz és Tar, 2010).

\section{A vizsgálat helyszíne}

A kisgyermekek vizsgálatára használt helyiség barátságos legyen, megfelelő hőmérséklettel. Nagysága legyen a nagymozgásos profilban szereplő feladatok elvégzéséhez szükséges méretü, de ha ez nem biztosított, akkor egy tágas folyosó, vagy még jobb esetben egy kisebb tornaterem álljon rendelkezésre. A vizsgálati teamben szereplő szakembereknek és természetesen a szülök részére is biztosítani szükséges a megfelelő méretü székeket. Szükség van egy nagyobb felületre, mely biztonságos és megfelelő alátámasztást nyújt a csecsemők vizsgálatához. Idősebb gyermekek esetén, kb. két éves kortól szükséges egy gyermek méretű asztal és hozzá tartozó szék, az önállóan, kis asztal mellett tevékenykedő gyermekeknek számára. A vizsgálati testhelyzetet a gyermek számára leginkább ismert pozícióban vegyük fel. A nyitott polcon csak azok az játéktárgyak legyenek kitéve, amelyek az aktuálisan vizsgált gyermek életkorának megfelelő játékra alkalmasak, a vizsgáló eszközök fokozatosan kerüljenek elő. A vizsgálati helyiség lehetőleg olyan helyen legyen, ahol minimalizálni lehet a zavaró tényezőket (zaj, fény).

\section{A SEED Fejlődési Skála bemutatása}

A SEED Fejlődési Skála egyénileg alkalmazható gyors obszervációs eljárás, 0-4 év között. Részleteiben átgondolt itemek biztosítják a fejlődési skála egyöntetűségét, ez lehetőséget ad arra, hogy az értékelés egyértelmű legyen, és a szubjektivitást minimalizálja.

A játékos próbák egy-egy életkor érdeklődési köréhez közel állóak, így a kevésbé nyitott, visszahúzódó gyermeknél is felkelthető az érdeklődés. Eredményre jutunk azokkal a gyermekekkel is, akik aktivitásuk fokozottsága miatt, vagy érdeklődésük be- 
szükülése okán nem minden feladatra nyitottak, mivel az eszközök a vizsgálati térben maradhatnak, és mivel a feladatok sorrendje nincsen meghatározva, bármikor, amikor a gyermek érdeklődését felkeltette, elvégezhetjük a próbát az adott eszközzel. A gyermek eszközökkel folytatott spontán tevékenysége is értékelhető.

Előnye még a vizsgálatnak, hogy a találkozás pillanatától tart a megfigyelés, maga a teszt felvétele viszonylag rövid időt vesz igénybe. Időkorlátozás (néhány feladat kivételével) nem szerepel benne. Az időfaktor természetesen a gyermek életkorával függ össze, mivel idősebb gyermekeknél több próba szerepel, de a gyermek feladatmegoldásainak idejét és általában véve pszichomotoros tempóját figyelembe vesszük a teljesítmény értékelésekor.

A vizsgáló eszközöket mindig úgy kínáljuk fel, hogy azokat a lehető legmagasabb szinten, vagyis a gyermek optimális fejlettségi szintjén tudja önállóan használni! A segítségnyújtás fokozatai egyben fejlődési szintek fokozatait is jelentik, így a vizsgálat felvételekor könnyen követhető, és meghatározható a gyermek valós fejlettségi szintje az adott fejlődési területen. Előnye és egyben kritériuma is a vizsgálatnak, hogy a szülő (a gyermekhez legközelebb álló gondozó) legyen mindig jelen a vizsgálaton. Nem csak gyermek biztonsága érdekében van erre szükség, hiszen biztonságban jobban teljesítenek a gyermekek, hanem azért is, mert az ő információit is elfogadjuk, értékeljük.

\section{SEED Fejlődési Skála szerkezeti felépítése}

A skála, fejlődési területenként és életkoronként különböző mennyiségű feladatot, kritériumot tartalmaz. A szakemberek megfigyelik a gyermek spontán tevékenységét és a konkrét feladatokban való aktív közremüködését. A feladatok száma az életkor függvényében növekszik. A skála 0-4 év közötti tartományban vizsgál, 1 héttöl 12 hónapos korig havi bontású, 1-2 év között 3 havonta ad mérési paramétereket, és 2 éves kor fölött fél éves beosztású. Ebből adódóan 21 szakaszra oszlik.

A skála 7 fejlődési területet vizsgál:

1. nagymozgás,

2. finommozgás,

3. beszéd és nyelv,

4. adaptáció, gondolkodás,

5. szociális-érzelmi fejlődés,

6. öltözködés és egyszerü tisztálkodás,

7. táplálkozás.

A nagy fejlődési területeken belül további, területenként változó alkategóriákra oszlik a skála.

A nagymozgáson belül vizsgáljuk a gyermek testtartását, fejkontrollját. A humanspecifikus mozgás fejlődés mérföldköveit fegyelembe véve a forgást, mászást, felülést, állást, járást. Speciálisabb helyzetekben a lépcsőzés, labdázás és az ugrás sajátosságait, amelyek meghatározott életkorokban érhetőek tetten.

Finommozgások vizsgálatánál a kézhelyzeteket, nyúlást, markolást és fogást, valamint az elengedés minőségét, változásait figyeljük meg.

A beszéd és nyelvi készségek területén belül a hallásválaszt és memóriát ellenőrizhetjük a befogadó nyelvi területtel. Ezek együttes értelmezése a beszédészlelésről ad képet. Emellett a kifejező nyelvi készségek, hangzók használata, a szavak megjelenése is nyomon követhető a különböző életkorokban. Itt jelennek meg a nyelvben kifejeződő szimbolikus gondolkodás elemei is, mint a színek egyeztetése, differenciálása és megnevezése. 
A szociális-érzelmi fejlődés területén a vizuális figyelem, vagyis a csecsemő, gyermek személyre orientáltsága, önmaga és mások megkülönböztetése, az imitáció, utánzás, a játék tevékenysége és a gyermek szocializációja kerül a megfigyelések fókuszába.

Amint a fejezet címében is szerepel az öltözködés és egyszerű tisztálkodási szokásokban mutatott fejlődési szintet követi ez a kategória.

A táplálkozás két alterületre oszlik: nyelv- és ajakreakciók, saját táplálkozási viselkedés.

A két utóbbi terület megjelenése a fejlődési skálában meglehetősen újszerü abban a tekintetben, hogy a gyermeki fejlődést valóban tágan értelmezi, nem szükíti le pusztán a kognitív és motoros funkciók, a beszéd vizsgálatára a szempontokat.

Az adaptáció, gondolkodás fejlődési szintjének felmérésénél a szükséges eszközök listáját és azokkal végzendő próbákat mutatja be a skála. Vizsgálja a vizuális figyelmet: fixálást, követést, a szemmozgásokat, a hallási figyelmet, lokalizációt, a tárgyakkal folytatott spontán aktivitást, manipulációt. Kognitív képességek terén az egyszerü ok-okozati összefüggések felismerését, a tárgyállandóság alakulását, az analízis-szintézis, formaészlelés, formadifferenciálás, és a nagyságdifferenciálás fejlődését.

Az egyes fejlődési területek vizsgálat természetesen nem elkülönítetten történik, hanem az adott időben és adott feladatvégzés közben globálisan, az abban megmutatkozott összes készséget, képességet megfigyeljük. Mivel egy gyermek minden területen fejlődik, ezért a gyermek erősségeinek és gyengéinek teljes képét csak akkor látjuk, ha az összes profilt áttekintjük. Minden terület egymással kapcsolatban áll, így egy eszközzel folytatott tevékenység során több fejlődési területre rálátunk, azt értékelni tudjuk. Például a kockákkal folytatott toronyépítés a gyermek finommotoros ügyességét és a gondolkodásában a konstrukció megjelenését is bemutatja, így a két fejlődési területet egyazon feladat elvégzése alapján értékelhetjük.

A skála feladatai táblázatba vannak rendezve, mind életkor specifikusan, mind fejlödési területek szerint, tehát egy adott életkorhoz tartozó itemek feladatsorai egy táblázatban jelennek meg. Ennek köszönhetően könnyen kezelhető ás könnyen áttekinthető.

\section{Az eredmény értékelése}

A SEED Fejlődési Skála tartalmaz minden fejlődési profilhoz egy ún. Egyéni profillapot, melyen a függőleges oszlopokban az életkorok, a sorokban pedig az adott fejlődési területhez tartozó részterületek szerepelnek. Az életkornak megfelelően egy függőleges színes, vastagabb vonalat húzva, és a részterületen elért életkori szintek rubrikáit kiszínezve rajzolódik ki az egyes fejlődési területekre jellemző egyéni, sajátos képességstruktúra.

A hat fő fejlődési terület átlag eredményeit pedig az ún. Mesterprofil-lapra vezethetjük fel. A kapott eredmények ilyen fajta vizuális megjelenítése pontosan láthatóvá, és a szülők számára is értelmezhetővé teszi a gyermek fejlettségi szintjét. 
A seed fejlődési skála mint a 0-4 éves korú gyermekek egyik vizsgáló eljárása ...

\begin{tabular}{|c|c|c|c|c|c|c|c|c|c|c|c|c|c|c|c|c|c|c|c|c|c|c|c|c|}
\hline \multirow{2}{*}{\multicolumn{2}{|c|}{$\begin{array}{l}\text { Névi: } \\
\text { Leirás }\end{array}$}} & \multicolumn{4}{|c|}{ Srületési dítum: } & \multicolumn{4}{|c|}{ Diagnózis: } & \multicolumn{5}{|c|}{$\begin{array}{l}\text { Keadeti entckelesi } \\
\text { diftum: }\end{array}$} & \multicolumn{5}{|c|}{$\begin{array}{l}\text { Elsó víróntéckési } \\
\text { dátum: }\end{array}$} & \multicolumn{5}{|c|}{$\begin{array}{l}\text { Mísodik ûjraértékelesi } \\
\text { dátum: }\end{array}$} \\
\hline & & 퐁 & $\frac{z}{7}$ & 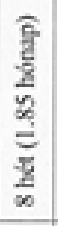 & 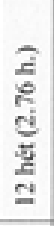 & 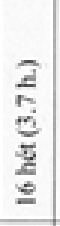 & 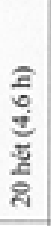 & 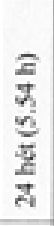 & 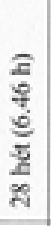 & 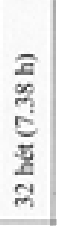 & 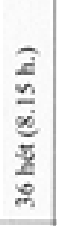 & 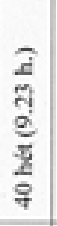 & 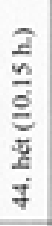 & 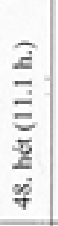 & $\frac{\underset{z}{z}}{\frac{3}{z}}$ & 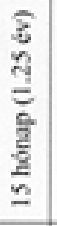 & 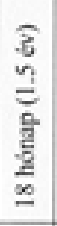 & 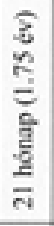 & 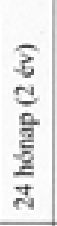 & 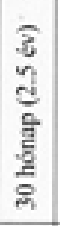 & 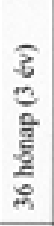 & 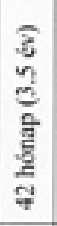 & 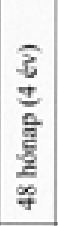 & 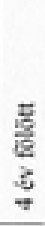 \\
\hline \multicolumn{25}{|c|}{$\begin{array}{l}\text { Szocialis- ́trzelmi } \\
\text { fejlódks }\end{array}$} \\
\hline \multicolumn{25}{|c|}{$\begin{array}{l}\text { Nagymorgás } \\
\text { fejlödes }\end{array}$} \\
\hline \multicolumn{25}{|c|}{$\begin{array}{l}\text { Finommotoros } \\
\text { fejlódes }\end{array}$} \\
\hline \multicolumn{25}{|c|}{$\begin{array}{l}\text { Adaptációs } \\
\text { gondolkodo } \\
\text { feilódés }\end{array}$} \\
\hline \multicolumn{15}{|c|}{ Receptiviv nyelvi } & & & & & & & & & & \\
\hline \multicolumn{25}{|c|}{$\begin{array}{l}\text { Expressziv nyelvi } \\
\text { fejlódés }\end{array}$} \\
\hline \multirow[t]{2}{*}{$\begin{array}{l}\text { Étkezési } \\
\text { fejlódés }\end{array}$} & $\begin{array}{l}\text { Nyelv, } \\
\text { ajak }\end{array}$ & & & & & & & & & & & & & & & & & & & & & & & \\
\hline & $\begin{array}{l}\text { Saját } \\
\text { et. v. }\end{array}$ & & & & & & & & & & & & & & & & & & & & & & & \\
\hline \multicolumn{2}{|c|}{$\begin{array}{l}\text { Ōltōzkōdés, } \\
\text { bygiénia }\end{array}$} & & & & & & & & & & & & & & & & & & & & & & & \\
\hline
\end{tabular}

\section{1. ábra: SEED Fejlődési Skála Mesterprofil lap}

A profillapok kitöltése lehetővé teszi a teszt tételek és a mögötte álló funkciók hálózatának kirajzolódását pontos képet alkotva így a gyermekek képességeinek struktúrájáról, hol, milyen fejlődési területen szükséges beavatkozni a fejlődés menetébe, illetve milyen terápiás, fejlesztési javaslatokat tegyünk ennek érdekében. A kvalitatív és kvantitatív értékelés, vagyis a számszerűsített eredmények és az egyéni képességstruktúra minőségi eltéréseinek leírása kerül megfogalmazásra a szakvéleményben.

\section{Kis mintán végzett longitudinális kutatás eredménye:}

Bár a SEED Fejlődési Skála alkalmazása a Budapesti Korai Fejlesztő Központban hosszú időszakra nyúlik vissza, mégis prediktív, előre jelző jellegét csak nemrég vizsgálta szakdolgozatában Stelczámer Ágnes munkatársunk

Kis létszámú csoport esetén vetette össze a gyermekek SEED Fejlődési Skálával végzett vizsgálatait az Intézménybe történő első vizsgálattól, iskolás korig, átlag 8-9 éves korig. A SEED Fejlődési Skálán elért eredményeket relatív elmaradási érték (fejlődésbeli eltérés/életkor) kiszámításával és rendszerezésével a következőket összegezhetjük:

A 14 főből 5 gyermek esetében fordul elő, hogy jelenleg normál tanmenettel tanul, egyéb probléma nélkül. Az ebbe a csoportba tartozó gyermekek esetében, a vizsgálati időpontok valamelyikében szerepel az életkorának megfelelő jelző.

Három esetben található autizmus spektrumzavar a jelenlegi, vagyis iskolás kori diagnózisban. Mindhárom esetnél a SEED Fejlődési Skála leíró markereiben jelentkeznek a beszéd-nyelv, szociális területen megjelenő minőségi eltérések, problémák.

Ismét 3 gyermek, akik normál tanmenet szerint tanulnak, de érzékszervi, mozgásszervi fogyatékos diagnózissal élnek. Érzékszervi fogyatékos 2 fő (gyengénlátó, 
nagyothalló) mozgásszervi fogyatékos 1 fö. A korábbi SEED Fejlődési Skálán mért vizsgálati eredményeik egyértelműen kimutatják fogyatékosságuk specializációját. (pl: mozgásszervi fogyatékos a mozgás területén kapott 0,34 relatív elmaradási értéket).

A SEED Fejlődési Skála prediktív jellegét leginkább felmutató újabb 3 fős csoport eredménye, akik iskolás korukban jelenleg eltérő tanmenetet követve haladnak. Esetük vizsgálatakor rajzolódott ki az eredmény (amelyet a speciális fogyatékkal élők részteljesítménye is megerősít), hogy ha a Skála korábbi eredményeit összesítve a fejlődési területek valamelyikén, vagy mindegyikén a relatív elmaradási érték közelíti, vagy meghaladja a 0,3-at, akkor a gyermek fejlődésmenete eltérően alakul, akadályozott lesz (Stelczámer, 2015).

A SEED Fejlődési Skála hosszú ideje tartó alkalmazása megerősítette a honosítókat abban, hogy érdemes az eszközt tesztminősítő folyamaton keresztül validitását és reliabilitását megvizsgálni. $E$ folyamat az idén veszi kezdetét. Sikeres eljárás esetén a hazai diagnosztikai palettán egy már régóta alkalmazott obszervációs eljárás válik vizsgáló eszközzé.

\section{Irodalom}

EADSNE - European Agency for Development in Special Needs Education (2010): Early Childhood Intervention - Progress and Developments 2005-2010. European Agency for Development in Special Needs Education, Odense, Denmark

Kereki Judit (2014): Majd kinövi (?) A koragyermekkori intervenciós rendszer és a korai fejlesztés TÁMOP-6.1.4. Koragyermekkori Továbbképzések IV., Hallgatói Kézikönyv, GYEMSZI, Budapest.

Lányiné Engelmayer Ágnes és Takács Katalin (2004): A fogyatékosság jelensége a pszichológiában. In: Zászkaliczky Péter és Verdes Tamás (szerk.): Tágabb értelemben vett gyógypedagógia. ELTE Bárczi Gusztáv Gyógypedagógiai Főiskolai Kar és Kölcsey Ferenc Protestáns Szakkollégium, Budapest, 233-268.

Lányiné Engelmayer Ágnes (2004): A Vineland szociális érettségi skála hazai alkalmazásának tapasztalatairól, In: Torda Ágnes (szerk.) Pszichodiagnosztika. Tanulmányok a gyógypedagógiai lélektan pszichodiagnosztikai eljárásainak köréböl

Matesz Monika és Tar Judit (2010): Fejlődési vizsgálatok a kora gyermekkor időszakában. Szemléleti kérdések. Módszertani alapelvek. Vizsgáló eljárások. Képzési anyag. Budapesti Korai Fejlesztő Központ, Budapest. 